\title{
JAUNDICE FOLLOWING PULMONARY INFARCTION IN PATIENTS WITH MYOCARDIAL INSUFFICIENCY
}

\author{
II. An Experimental Study
}

By WILLIAM H. RESNIK AND CHESTER S. KEEFER

(From the Medical Clinic, School of Medicine, Johns Hopkins University)

(Received for publication January 30, 1926)

\section{INTRODUCTION}

In a preceding paper (Keefer and Resnik (1926)) we described ten patients suffering from myocardial insufficiency, in whom jaundice appeared for the first time or increased considerably if already present following the development of pulmonary infarction.

It is apparent that pulmonary infarction in a patient suffering from heart failure involves more than the mere extravasation of blood into the lungs. The experimental work of Binger, Brow and Branch (1924) shows that the chief functional disturbance which occurs as a result of pulmonary embolism is the development of anoxic anoxemia, a state in which the arterial blood contains less than its normal quota of oxygen. Undoubtedly, anoxemia of a similar kind developed in the patients whose histories we have reported. While it is true that in the experiments of Binger, Brow and Branch it was only after multiple embolisms had taken place that anoxemia appeared, and that in some of our patients on the contrary only one infarct occurred, it must be remembered that the circumstances differ in the two instances. In the experiments of Binger, Brow and Branch, the animals and the lungs were normal. A considerable amount of mechanical obstruction of the pulmonary circulation must take place before the functional impairment of the lungsis sufficiently great to produce anoxic anoxemia. On the other hand,it is altogether reasonable to assume that, in patients such as we have described, in whom there is already functional impairment of the lungs, due to chronic passive congestion, still further 
diminution in the amount of effective pulmonary tissue may bring on anoxic anoxemia, or exaggerate the degree of anoxemia already present.

There is another factor of prime importance. All the patients in whom jaundice appeared following pulmonary infarction died within a relatively short time of progressive myocardial failure. There is evidence to show that anoxemia depresses myocardial function, particularly when the myocardium is already damaged (Resnik, 1925); so that the effect of pulmonary infarction in patients with myocardial failure is not only to cause anoxic anoxemia to appear, but also to increase the degree of stagnant anoxemia, which is dependent on the development of diminished circulatory minute volume.

Finally, the condition of the liver remains to be considered. Since all our patients were suffering from severe and long standing myocardial insufficiency, it is probable that at the time when pulmonary infarction developed there must have been present changes in the liver characteristic of chronic passive congestion. Since according to contemporary theories of jaundice (McNee, 1922), (Rich, 1925), it is the function of the hepatic cells to excrete the bile pigment that is brought to them by the blood stream; the functional efficiency of these cells must be kept clearly in mind.

In pulmonary infarction in patients with myocardial failure, we must deal, then not only with extravasation of blood into the pulmonary tissues, but with the functional disturbances that such a lesion may bring about. To state the case more directly: It is possible that anoxemia, which is caused by pulmonary and circulatory impairment, resulting from pulmonary infarction, may depress the excretory function of already damaged liver cells to such an extent that jaundice appears. The experiments now to be described had as their object a study of the effect of anoxemia on the damaged liver.

\section{EXPERIMENTAL METHODS}

To produce a liver lesion that would simulate the condition of chronic passive congestion, we had recourse to the use of carbontetrachloride. When this substance is given by mouth, a central lesion of the liver lobule occurs (Lamson, Gardner, Gustafson, Maire, McLean and Wells (1923)), (Gardner, Grove, Gustafson, Maire, Thompson, Wells and Lamson, (1925)). The liver injury reaches its maximum 
within 24 to 48 hours, and healing begins three or four days after administration.

Dogs were given carbontetrachloride by stomach tube, in doses of 4 cc. per kilo of body weight. Twenty-four hours later, they were anesthetized by the subcutaneous injection of morphine, approximately $6 \mathrm{mg}$. per kilo, followed by the administration of urethane, 1 gm. per kilo, given in watery solution by stomach tube.

Through a Y-shaped tracheal cannula, a catheter was inserted down to the bifurcation of the trachea, the catheter being connected with a tank of nitrogen. Anoxemia, of any desired degree, was produced by varying the amount of nitrogen flowing into the lungs. The degree of anoxic anoxemia was determined by analysis of samples of blood taken from the femoral artery. Analyses of the oxygen content and capacity of the blood were made by the methods of van Slyke. On a few occasions, similar analyses of the venous blood were made, in order to ascertain the degree of stagnant anoxemia. Samples of blood for the determination of the bilirubin content were taken usually from the femoral vein, occasionally from the femoral artery. The blood was drawn into tubes containing a few crystals of sodium oxalate, the amount of bilirubin being estimated by the modification of the van den Bergh test recently described by McNee and Keefer (1925). When the urine was tested in order to find whether bile pigment was present, the Salkowski modification of the Huppert test was employed. In several experiments, the presence of hematin in the blood was sought, by spectroscopic analysis of the plasma, using the Leitz spectroscope attachment for the microscope.

The general procedure in the experiments was to estimate the bilirubin content of the blood at intervals, while the animal was breathing air, usually with an added quota of oxygen. ${ }^{1}$ After several hours, anoxemia was induced, and bilirubin determinations of the blood were made again at intervals. Since the exact procedure differed in individual experiments, the details are given in the protocols. On completion of an experiment, pieces of liver were removed for histological examination, and other observations were made which will be recorded in the protocols.

\footnotetext{
${ }^{1}$ It will be understood that whenever the bilirubin content of the blood is mentioned, it is actually to the blood plasma or serum that the reference is made.
} 


\section{RESULTS OF EXPERIMENTS}

Dog 1. Weight 11 pounds. This animal was used as a control. In order to test the effect of anoxemia on the normal liver carbontetrachloride was not given. At the beginning of the experiment, $35 \mathrm{cc}$. of the animal's own blood was injected intraperitoneally; considering the size of the dog, this was the equivalent of a fairly large extravasation of blood. This was done because in some of the other experiments, there was extravasation of a certain amount of blood into the peritoneal cavity due to operative procedure; although it was improbable

TABLE 1

Dog 1. Effect of anoxemia on the bilirubin content of blood of an anima! wiih a normal liver

\begin{tabular}{|c|c|c|c|c|}
\hline Time & $\begin{array}{c}\text { Oxygen } \\
\text { saturation } \\
\text { of arterial } \\
\text { blood }\end{array}$ & $\begin{array}{l}\text { Bilirubin } \\
\text { content of } \\
\text { blood } \\
\text { plasma }\end{array}$ & $\begin{array}{l}\text { Hematin } \\
\text { in blood } \\
\text { plasma }\end{array}$ & Remarks \\
\hline $\begin{array}{l}9.45 \text { a.m. } \\
11.15 \text { a.m. } \\
11.35 \text { a.m. } \\
1.55 \text { p.m. } \\
3.15 \text { p.m. } \\
5.00 \text { p.m. } \\
5.01 \text { p.m. } \\
6.00 \text { p.m. } \\
6.01 \text { p.m. } \\
6.30 \text { p.m. } \\
6.35 \text { p.m. }\end{array}$ & $\begin{array}{c}\text { per cent } \\
95^{*} \\
\\
56 \\
56 \\
56 \\
56 \\
56 \\
<56 \\
56 \\
56 \\
56\end{array}$ & $\begin{array}{l}0 \\
0 \\
0 \\
0 \\
0 \\
0\end{array}$ & $\begin{array}{l}0 \\
0 \\
0 \\
0 \\
0 \\
0\end{array}$ & $\begin{array}{l}\text { Flow of nitrogen to !ungs started } \\
\text { Flow of nitrogen increased } \\
\text { Flow of nitrogen further increased } \\
\text { Animal died }\end{array}$ \\
\hline
\end{tabular}

* This figure is approximate; the arterial blood was at least 95 per cent saturated with oxygen, since the breathing mixture was enriched with oxygen.

that, during the relatively short duration of a single experiment, the presence of blood in the peritoneal cavity could have had any effect on the bilirubin content of the blood.

The results of the experiment are summarized in table 1.

Autopsy. The bile passages were patent. The urinary bladder contained $80 \mathrm{cc}$. urine, which was free of bile pigment. Blood was present in the peritoneal cavity, approximately similar in amount to that injected. Histological examination of the liver showed slight but definite central necrosis of the liver lobules. We shall return later to a discussion of the significance of this finding. 
Comment. Extremely severe anoxemia, of over seven hours duration, had no effect in increasing the bilirubin content of the blood of this animal, whose liver, at the beginning of the experiment was normal. There was moreover no evidence that the presence of free blood in the peritoneal cavity caused the appearance of hematin in the blood during the period of the observations.

Dog 2. Weight 25 pounds; 4 cc. carbontetrachloride administered 24 hours previously.

TABLE 2

Dog 2. Effect of anoxemia on the bilirubin content of the blood of an animal with injured liver

\begin{tabular}{|c|c|c|c|}
\hline Time & $\begin{array}{l}\text { Oxygen } \\
\text { saturation of } \\
\text { arterial blood }\end{array}$ & $\begin{array}{c}\text { Bilirubin } \\
\text { content of blood } \\
\text { plasma }\end{array}$ & Remarks \\
\hline & per cent & units & \\
\hline 10.10 a.m. & 92 & 0 & $\begin{array}{l}\text { Hemolyzed blood in plasma of every } \\
\text { sample of blood }\end{array}$ \\
\hline 1.10 p.m. & 92 & $\mathbf{0}$ & \\
\hline 3.00 p.m. & 92 & & \\
\hline 3.10 p.m. & 92 & $\mathbf{0}$ & \\
\hline 4.10 p.m. & 93 & $\mathbf{0}$ & \\
\hline 4.50 p.m. & 93 & 0 & \\
\hline 5.10 p.m. & 72 & & Arterial anoxemia* \\
\hline 5.55 p.m. & 72 & 0 & \\
\hline 7.35 p.m. & 72 & Trace & \\
\hline 8.46 p.m. & $<72 \dagger$ & 0.75 & \\
\hline 9.45 p.m. & 72 & 0.75 & \\
\hline 10.45 p.m. & 72 & 0.75 & \\
\hline 11.35 p.m. & 72 & 0.75 & Immediately after death \\
\hline
\end{tabular}

* Actually, the flow of nitrogen was started at 2.00 p.m. Analyses of the arterial blood at 3.00 p.m. and at 4.00 p.m. showed, however, that the arterial blood was normally saturated. This was undoubtedly due to the fact that respiration was stimulated sufficiently to compensate for the slightly increased percentage of nitrogen in the inspired gas. At 5.10 p.m. the percentage of nitrogen in the breathing mixture was increased, analysis at this time showing that the arterial blood was 72 per cent saturated. Anoxemia must be considered, then, to have begun at this time.

† From 8.00 p.m. on, there was present not only anoxic anoxemia, but also stagnant anoxemia, the extent of which was not determined. We make this statement, because the animal was in poor condition. In order to prolong the experiment as long as possible, the flow of nitrogen was discontinued at 8.00 p.m. and at 10.30 p.m. for about 10 minutes each time. During this time, a rich mixture of oxygen was given. In spite of the fact however that the arterial blood was rendered bright pink, the mucous membrane of the tongue remained distinctly cyanotic, indicating that the blood flow through the tissues was impaired. The degree of anoxemia was really greater, then, than would appear from the figure in the table. 
Autopsy. The bile passages were patent. The urinary bladder held $120 \mathrm{cc}$. urine which contained a trace of bile pigment (the exact amount was not determined). The lungs were normal. Histological examination of liver tissue show marked central necrosis of the liver lobule.

Comment. In this animal in which the liver had been damaged by the administration of carbontetrachloride, there was no bilirubin in the blood over a period of seven hours when the arterial blood was normally saturated with oxygen. Two and a half hours after inducing a fairly severe anoxemia, there was a trace of bilirubin in the blood, the amount increasing to 0.75 unit an hour later. Thereafter there was no increase. The anoxemia which was present was not only of the anoxic type, but also of the stagnant type.

On centrifuging each specimen of blood, it was found that there was constantly present a slight amount of hemolyzed blood in the supernatant plasma. That this was not due to oxalate is shown by the fact that a similar finding was observed when the blood was allowed to clot. ${ }^{2}$ Although bilirubinemia might have occurred owing to injury of the liver and probably an increase in the formation of bile pigment due to the presence of free hemoglobin in the circulating blood, bilirubinemia did not appear until anoxemia was induced.

Dog 3. Weight 41 pounds; 4 cc. per kilo of carbontetrachloride given 24 hours previously. Kidney pedicles tied. In the experiment just described $(\operatorname{dog} 2)$, there exists the possibility, even though unlikely, that the increase of bilirubin in the blood was due partly to depression of kidney function as the result of anoxemia. Because of this possibility, the entire pedicle of each kidney was securely ligated. ${ }^{3}$

Autopsy. The bile passages were patent. The renal artery, vein, and the ureter were securely ligated on both sides. There was about 25 to $30 \mathrm{cc}$. of free blood in the peritoneal cavity, due to the operative procedure. The lungs were normal. Histological examination of the liver showed central necrosis of the liver lobules.

Comment. During the control period, when the arterial blood was

${ }^{2}$ Lamson, Gardener et al. (1923) have also found intramuscular hemolysis, although apparently less frequently than we have.

${ }^{3}$ This was done, rather than removal of the kidneys, in order to avoid, so far as possible, surgical shock. 
TABLE 3

Dog 3. Effect of anoxemia on the bilirubin content of the blood of an animal with injured liver

\begin{tabular}{c|c|c|c}
\hline Time & $\begin{array}{c}\text { Oxygen } \\
\text { saturation of } \\
\text { arterial blood }\end{array}$ & $\begin{array}{c}\text { Bilirubin content of } \\
\text { blood plasma }\end{array}$ & Remarks \\
\cline { 1 - 2 } per cent & $\begin{array}{c}\text { units } \\
95 ?^{*}\end{array}$ & Faint trace? & $\begin{array}{c}\text { Hemolyzed blood in plasma of every } \\
\text { sample of blood }\end{array}$ \\
10.25 a.m. & 95 & Faint trace? & \\
1.35 p.m. & 57 & & Flow of nitrogen started \\
2.00 p.m. & 57 & Definite trace & \\
2.35 p.m. & 57 & 1.1 & Sample taken immediately after death \\
3.05 p.m. & 57 & 1.5 & p.m.
\end{tabular}

* Analysis not done. Dog was breathing air enriched with oxygen.

TABLE 4

Dog 4. Effect of anoxemia on bilirubin content of the blood of an animal with injured liver

\begin{tabular}{|c|c|c|c|}
\hline Time & $\begin{array}{c}\text { Oxygen } \\
\text { saturation of } \\
\text { arterial blood }\end{array}$ & $\begin{array}{l}\text { Bilirubin content of } \\
\text { blood plasma }\end{array}$ & Remarks \\
\hline & per cent & units & \\
\hline 10.30 a.m. & 95?* & Faint trace & $\begin{array}{l}\text { Condition poor. Tongue cyanotic in } \\
\text { spite of high percentage of oxygen } \\
\text { in breathing mixture }\end{array}$ \\
\hline 1.30 p.m. & 95 & 1.56 & \\
\hline 1.50 p.m. & 95 & & $\begin{array}{l}\text { Condition of animal poor. Oxygen } \\
\text { saturation of the femoral vein } 35.7 \\
\text { per cent }\end{array}$ \\
\hline 2.30 p.m. & 95 & 1.50 & \\
\hline 3.38 p.m. & 95 & 1.56 & \\
\hline 4.30 p.m. & 87.4 & & $\begin{array}{l}\text { Added flow of oxygen discontinued. } \\
\text { Animal breathing air. Respirations } \\
\text { shallow }\end{array}$ \\
\hline 4.35 p.m. & 87.4 & 1.50 & \\
\hline 5.35 p.m. & 87.4 & 1.60 & \\
\hline 6.45 p.n & 87.4 & & \\
\hline 7.45 p.m. & 87.4 & 1.75 & \\
\hline 8.45 p.m. & 87.4 & 1.88 & \\
\hline 9.45 p.m. & 87.4 & 2.8 & \\
\hline 11.35 p.m. & 87.4 & 1.56 & Sample taken immediately after death \\
\hline
\end{tabular}

* Oxygen content was not done. Animal was inspiring an oxygen-rich mixture of gas. The arterial blood was bright pink and was probably 95 per cent saturated with oxygen. 
normally saturated with oxygen, there was a questionable trace of bilirubin in the blood. One-half hour after severe anoxemia was induced, there was a definite increase in the amount of bilirubin of the blood, the amount reaching 1.5 units at the time of death of the animal, about two hours later.

Dog 4. Weight 12 pounds; carbontetrachloride, 4 cc. per kilo, given by stomach tube 24 hours previously. Kidney pedicles tied.

Autopsy. The bile passages were patent. There was free blood, 15 to $20 \mathrm{cc}$, in the peritoneal cavity. The entire kidney pedicle was securely ligated on both sides. Histological examination of the liver showed extensive central necrosis of the liver lobule.

Comment. Because of profound operative shock, there was present throughout the entire experiment a considerable degree of stagnant anoxemia, as evidenced by the low oxygen saturation of the venous blood (see table 4 , at 1.50 p.m.) while at the same time the arterial blood was normally saturated with oxygen. This we believe was responsible for the increase in the bilirubin content of the blood from a trace to 1.56 units three hours later. At 4.30 p.m., the added supply of oxygen to the inspired air was discontinued. The respirations then became slow and shallow, probably because arterial oxygen saturation diminished to 87.4 per cent. In other words, there was superimposed on stagnant anoxemia, an anoxic anoxemia, although of relatively mild degree. The bilirubin content of the blood then began to increase steadily, reaching its maximum five hours later; the bilirubin concentration of the blood was 2.8 units at this time. About two hours later the animal died: $A$ sample of blood taken from the heart immedately after death showed that the bilirubin concentration had decreased to 1.56 units.

Every sample of blood was found to contain free hemoglobin in the plasma. At no time, however, was hematin detected in the plasma by spectroscopic examination.

Dog 5. Weight 11 pounds; carbontetrachloride, 4 cc. per kilo, administered 24 hours previously. In order to avoid the operative shock consequent on ligating the kidney pedicles, a cannula was inserted in the urinary bladder. In this way, changes in the bile pigment content of the urine could be detected at intervals during the experiment.

Autopsy. The bile passages were patent. There was no blood in 
the peritoneal cavity. Near the roots of the lungs there were a few small patches of edema and atelectasis. Histological examination of the liver showed central necrosis of the liver lobule.

Comment. During the control period, when the arterial blood was normally saturated with oxygen, the faint trace of bilirubin in the blood, which was present on the first examination, disappeared. One hour after the beginning of anoxemia, bilirubin reappeared in the blood, increasing to 0.8 unit shortly before the death of the animal, about six hours after anoxemia was produced.

TABLE 5

Dog 5. Effect of anoxemia on the bilirubin content of the blood of an animal with injured liver

\begin{tabular}{|c|c|c|c|c|}
\hline Time & $\begin{array}{c}\text { Oxygen } \\
\text { saturation } \\
\text { of arterial } \\
\text { blood }\end{array}$ & $\begin{array}{l}\text { Bilirubin content of } \\
\text { blood plasma }\end{array}$ & $\begin{array}{l}\text { Bilirubin content } \\
\text { of urine }\end{array}$ & Remarks \\
\hline 10.30 a.m. & $\begin{array}{l}\text { per cent } \\
95 ?\end{array}$ & $\begin{array}{c}\text { units } \\
\text { Faint trace? }\end{array}$ & 0 & $\begin{array}{l}\text { Content not determined. } \\
\text { Breathing an oxygen rich } \\
\text { mixture. Condition of } \\
\text { animal excellent }\end{array}$ \\
\hline $\begin{array}{r}12.30 \text { p.m. } \\
2.35 \text { p.m. } \\
4.30 \text { p.m. }\end{array}$ & $\begin{array}{l}95 \\
95 \\
95\end{array}$ & $\begin{array}{c}\text { Faint trace? } \\
0 \\
0\end{array}$ & $\begin{array}{l}\mathbf{0} \\
\mathbf{0}\end{array}$ & \\
\hline 4.31 p.m. & 66 & & & $\begin{array}{l}\text { Flow of nitrogen to lungs } \\
\text { started }\end{array}$ \\
\hline $\begin{array}{l}5.30 \text { p.m. } \\
6.20 \text { p.m. }\end{array}$ & $\begin{array}{l}66 \\
66\end{array}$ & $\begin{array}{l}\text { Faint trace } \\
\text { Definite trace }\end{array}$ & & \\
\hline 8.00 p.m. & 66 & 0.6 & Faint trace & \\
\hline 8.45 p.m. & 66 & 0.6 & & \\
\hline $\begin{array}{l}9.45 \text { p.m. } \\
10.50 \text { p.m. }\end{array}$ & $\begin{array}{l}66 \\
66\end{array}$ & $\begin{array}{l}0.75 \\
0.8\end{array}$ & Faint trace & Sample taken one-half hour \\
\hline
\end{tabular}

There was no intravascular hemolysis in this animal.

Dog 6. Weight 19 pounds; carbontetrachloride was not given to this animal. In all previous experiments, in which liver injury had been caused by the administration of carbontetrachloride, there was an increase in the bilirubin content of the blood within a relatively short time after anoxemia was instituted. The increase of bilirubin in the blood may, it appeared, have been due to increased formation of bilirubin during periods of anoxemia. The damaged liver may, under 
ordinary circumstances, have been able to excrete the amount of bilirubin which was normally formed; but during anoxemia the production may have been excessive so that the liver was taxed beyond its capacity, with the result that bilirubin began to accumulate in the blood.

The cystic duct was ligated and a cannula was inserted in the common bile duct and connected with a rubber tube leading out through the abdominal wound. The kidneys were not removed or isolated, but the urine in the bladder at the end of the experiment was entirely free of bile pigment. Consequently, by determinations of the bilirubin content of the blood and the bile, we obtained information concerning the amount of bilirubin which was being formed during a given period of time. There was no intravascular hemolysis, nor was there any blood in the peritoneal cavity at autopsy. Abnormal blood destruction was in this case then not the cause of increased bile pigment formation.

Although it has been shown by Rous, Brown and McMaster (20) that erroneous impressions of the output of bile pigment may be gained in bile-fistula experiments, when the periods of collection are of short duration, we were nevertheless obliged to use short collection periods; first, because of the nature of the experiment; and, second, because in our other experiments, the changes in bilirubin content in the blood had occurred within a relatively short period of time after anoxemia was produced. The collections of bile were made in periods of two and three hours. The amount in a single period was made up to a total of $100 \mathrm{cc}$. with distilled water and the quantity of bilirubin was then determined by the van den Bergh test. The number of units found in the diluted specimen was divided by the number of hours during which the collection was made, giving the number of units of bilirubin per hour. The rubber tube leading to the container in which the bile was collected was not emptied at the end of each collection period. It is possible, therefore, that an error was introduced through the circumstance that the rubber tube may have contained varying amounts of bile at different times. This error, if it existed, must, however, have been slight.

Autopsy. The cystic duct was securely ligated and the passage between the common duct and the cannula was patent. There was no 
bile pigment in the urine of the urinary bladder. There was practically no free blood in the peritoneal cavity. Histological examination of the liver showed slight but definite central necrosis of the liver lobules.

Comment. Since the blood and urine were entirely free of bilirubin, the bile which was collected from the common duct must have contained the total output of this pigment. We do not wish to stress the actual amounts of bilirubin that were excreted. ${ }^{4}$ But the presence of

TABLE 6

Dog 6. Effect of anoxemia on the rate of formation of bilirubin

\begin{tabular}{|c|c|c|c|c|c|c|c|}
\hline Period & Time & $\begin{array}{c}\text { Dura- } \\
\text { tion of } \\
\text { colloce- } \\
\text { tion }\end{array}$ & $\begin{array}{l}\text { Oxygen } \\
\text { satura- } \\
\text { tion of } \\
\text { arterial } \\
\text { blood }\end{array}$ & $\begin{array}{c}\text { Output } \\
\text { of } \\
\text { bile }\end{array}$ & $\begin{array}{l}\text { Output } \\
\text { of bili- } \\
\text { rubin }\end{array}$ & $\begin{array}{c}\text { Bili- } \\
\text { rubin } \\
\text { content } \\
\text { of blood } \\
\text { plasma }\end{array}$ & Remarks \\
\hline & & hours & per cent & $\begin{array}{l}\text { ce.per } \\
\text { hour }\end{array}$ & $\begin{array}{c}\text { units per } \\
\text { hour }\end{array}$ & units & \\
\hline 1 & $\begin{array}{l}11.40 \text { a.m. to } \\
2.40 \text { p.m. }\end{array}$ & 3 & 96 & 4.5 & 18.7 & 0 & $\begin{array}{l}\text { Slight operative shock. } \\
\text { Venous blood was } 56 \text { per } \\
\text { cent saturated with } \\
\text { oxygen }\end{array}$ \\
\hline 2 & $\begin{array}{l}2.40 \text { p.m. to } \\
5.40 \text { p.m. }\end{array}$ & 3 & 73 & 4.06 & 11.3 & 0 & $\begin{array}{l}\text { Condition of animal im- } \\
\text { proving }\end{array}$ \\
\hline 3 & $\begin{array}{l}5.40 \text { p.m. to } \\
7.40 \text { p.m. }\end{array}$ & 2 & 73 & 3.75 & 17.0 & 0 & $\begin{array}{l}\text { Animal in excellent con- } \\
\text { dition. Required mor- } \\
\text { phia grain } \frac{1}{6}\end{array}$ \\
\hline 4 & $\begin{array}{l}4.40 \text { p.m. ro } \\
9.35 \text { p.m. }\end{array}$ & 2 & ? & 3.15 & 19.0 & 0 & $\begin{array}{l}\text { No gas analysis made. } \\
\text { This is a probable figure }\end{array}$ \\
\hline 5 & $\begin{array}{l}9.35 \text { p.m. to } \\
11.30 \text { p.m. }\end{array}$ & 2 & $?$ & 1.5 & 7.0 & 0 & $\begin{array}{l}\text { No gas analysis made. } \\
\text { This is a probable figure }\end{array}$ \\
\hline
\end{tabular}

4 McMaster, Broun, and Rous (1923) have found that, in dogs with normal hemoglobin content, the maximum output of bilirubin was $11 \mathrm{mg}$. per kilo of dog in 24 hours. If our own figures are translated into corresponding terms; they are for the respective periods: $26.4,16.0,23.8,26.5$ and $9.8 \mathrm{mg}$. per kilo in 24 hours. Although the conditions differed in the two sets of experiments, we are still unable adequately to account for the greater yield which we obtained. Because of this discrepancy, we have hesitated to report this experiment, and to draw conclusions from it which may not be justified; namely that anoxemia may depress the formation of bile pigment. Unfortunately, owing to certain circumstances, we were unable to repeat the experiment, and we have described it because it does seem to explain why the bilirubin content of the blood diminished in experiment 4 even though there was every reason to believe that the liver injury was increasing. 
anoxemia did not serve to increase the formation of bilirubin. Indeed, the amount of bilirubin obtained during the periods of anoxemia was always less than that obtained when the blood was normally saturated with oxygen. The diminution in bilirubin output was particularly striking in Period 5 when the output fell to about one-third the amount of the preceding period.

SUMMARY AND DISCUSSION OF EXPERIMENTS ON THE EFFECT OF ANOXEMIA

We may now bring together the various findings that have been observed in these experiments. It has been demonstrated that when the liver of a dog has been injured by the administration of carbontetrachloride, anoxemia, whether of the anoxic or of the stagnant type, is followed by definite and sometimes striking increase in the bilirubin content of the blood. It has also been shown that severe anoxemia, of several hours duration, fails to bring about this result if the liver has not been previously injured. Finally, it has been shown that the accumulation of bilirubin in the blood is not due to depression of renal function, or to increased formation of bilirubin. We draw the conclusion therefore that in our experiments anoxemia affected the liver in such a way that bilirubinemia appeared, or if it was already present, was exaggerated. The evidence that we possess at the present time indicates that the sole function of the hepatic cell, so far as bilirubin is concerned, is to excrete this pigment. We can, therefore, go further and state that the mechanism by which anoxemia causes bilirubinemia to develop under the conditions of our experiments serves to impair the capacity of the hepatic cell to excrete bilirubin.

There are two observations that need further comment. In the experiment on $\operatorname{dog} 4$ (table 4), the bilirubin content of the blood reached a maximum of 2.8 units during anoxemia. Two hours later, immediately after the animal expired, the bilirubin concentration of the blood had diminished to 1.56 units. The decrease could hardly have been due to improvement in the excretory ability of the liver cells, since the degree of anoxemia was more severe than it had been when the bilirubin content of the blood was 2.8 units. If the function of the liver were the only factor concerned the amount of bilirubin in the blood should have continued to increase. The solution of this 
difficulty is apparently supplied by the results obtained in the experiments on dog 6 (table 6). Here it was found in period 5 that after severe anoxemia the formation of bilirubin was sharply diminished. Whether the decreased output of bilirubin during this period was due to diminished breakdown of blood pigment, an accepted source of bile pigment; or whether it was due to functional impairment of the agency which transforms blood pigment into bile pigment, we do not know. At any rate, anoxemia seems to bring about two mutually antagonistic effects: 1 , depression of the ability of the liver cell to excrete bilirubin, this factor tending to increase the bilirubin content of the blood; 2, depression of bilirubin formation (of significance, probably, only in the late stages of anoxemia), tending to decrease the bilirubin content of the blood. The result depends on the balance of these effects; and the explanation for the diminution of the amount of bilirubin in the blood in dog 4 lies, undoubtedly, in the fact that the second effect predominated at the end of the experiment.

Another observation of considerable interest was that concerning the influence of anoxemia on the normal liver. It will be recalled that the experiments on dogs 1 and 6 were made without the administration of carbontetrachloride, so that the livers of these animals were presumably normal at the beginning of the experiments. Yet in both instances, histological examination of liver tissue removed immediately after death showed slight central necrosis. This finding probably throws light on the origin of the liver lesion which results from chronic passive congestion. Anoxemia of the stagnant type, while it is not the only functional disturbance that occurs as a result of myocardial insufficiency, is a constant one. It seems probable, therefore, that anoxemia may not only impair the function of the already damaged liver, but it may actually be responsible, at least in part, for the damage.

Finally, it may be mentioned that in none of the experiments was hematin found in the plasma although in several there was either intravascular hemolysis or extravasation of blood into the peritoneal cavity, conditions under which hematinemia has previously been found before (Schottmüller, 1914). 


\section{DISCUSSION}

It remains to discuss the clinical bearing of the foregoing observations, particularly with reference to their relation to jaundice in myocardial failure. This may best be done, perhaps, by enumerating the various factors which may enter into the causation of jaundice under these circumstances.

1. Impairment of liver function. We refer specifically to the function of the hepatic cell to excrete bilirubin. Experimentally, it has been shown that the degree of bilirubinemia produced by drugs such as carbontetrachloride (Lamson, et al., 1923), which cause a diffiuse lesion in the liver is generally proportional to the severity of the liver injury. Clinically, too, we have found that, in general, the same relationship is true. Patients suffering from myocardial failure who show latent or outspoken jaundice are practically always those whose myocardial failure is more or less severe and of long duration. Probably in every case of myocardial failure in which jaundice occurs, one may find extensive anatomical changes in the liver. We believe, therefore, that one of the most important and constant factors in the production of "cardiac" jaundice is the functional impairment of the liver cells, the final result, however, being modified by other influences. It has been pointed out (Fishberg, 1923), that there are patients with intense congestion of the liver, particularly in cases of heart failure of recent origin, in whom the bilirubin content of the blood is not much increased; and, on the other hand, there are patients with high blood bilirubin values in the blood whose livers are not large enough to be palpable. It must be emphasized, however, that the size of the liver does not necessarily give a correct idea of the anatomical changes in the liver or of its functional impairment. It is particularly in the recent cases of myocardial insufficiency with greatly swollen livers that one may find least liver damage on histological examination. Conversely, one may find the most intense central necrosis of the lobules of livers which, because of severe and long standing congestion and consequent necrosis and collapse of the lobules, have become even smaller than normal in size.

2. Anoxemia. We have seen that, in the experiments, anoxemia may depress the function of livers already damaged to such an extent 
that the bilirubin content of the blood increases strikingly. We have also pointed out that pulmonary infarction may produce anoxemia in patients with severe myocardial insufficiency. It is probably through the effect of anoxemia on liver function that jaundice develops, or increases in patients such as those whose histories we have given in detail in an earlier paper. Anoxemia probably depresses liver function in any circumstance, and we have obtained evidence to show that it may actually be responsible, in part at least, for liver damage in chronic passive congestion. Anoxemia of short duration, even if severe, fails however of itself to cause a sufficiently profound depression of liver function to permit the development of jaundice. There must be, in addition to anoxemia, a certain degree of functional impairment of the liver, in order that jaundice may follow.

3. Increased destruction of red blood cells. Since Resnik and Rich (1926) were unable to obtain conclusive evidence that local extravasations of blood in patients with severe myocardial failure such as one sees after pulmonary infarction caused sudden increase in the bilirubin content of the blood, we cannot accept the view that jaundice that develops under these circumstances is caused primarily by the absorption of locally formed bilirubin. We do not mean to imply, however, that increased blood destruction plays no rôle in the development of "cardiac" jaundice. The evidence that there is increased blood destruction and bilirubin formation in myocardial insufficiency was fairly well established (Eppinger, 1923). One must conclude, therefore, that since the ability of the liver to excrete bilirubin is already impaired in myocardial failure, the degree of bilirubin retention in the blood stream must be enhanced by the abnormally large amount that the liver must deal with. It is posible, perhaps, that the bilirubin that is formed locally about an infarct may increase to some extent the amount of bilirubin that accumulates in the blood. It has been our purpose, however, to show that the absorption of bilirubin formed locally about an infarct is not the primary cause.

4. Impairment of bilirubin formation. We do not know the agency which forms bilirubin. It is obvious that under different conditions bodily functions are carried out at different levels of efficiency, and in jaundice one must naturally consider the matter of the bilirubin formed under those conditions. We have seen, in the experiment on $\operatorname{dog} 4$ 
(table 4) that the bilirubin content of the blood may decrease even though there is every reason to believe that the liver damage is increased; and in the experiment on $\operatorname{dog} 6$ it was found that the explanation probably lay in the diminution in the amount of bilirubin that was formed. Whether this diminution in bilirubin formation was actually due to impairment of the function of the agency which forms bilirubin, we do not know. Such a possibility exists, however; and although it is rarely of great significance, it must be taken into account if every factor concerned with the cause of jaundice in myocardial insufficiency is reckoned with. We have observed in patients as well as in experimental animals a discrepancy in the amount of bilirubin actually in the blood and that which we expected to find. The following case is an instance.

A woman with severe myocardial insufficiency and pronounced jaundice improved temporarily under the usual therapeutic measures. Following an attack of acute tonsillitis, she became rapidly worse and after several weeks died of progressive myocardial failure. Toward the end there was generalized infection with streptococcus hemolyticus. In spite of the fact that myocardial failure was extreme, and the liver at necropsy showed extensive necrosis, the bilirubin content of the blood was only 0.8 unit a few days before the death of the patient.

5. Impairment of renal function. We have not actually investigated the relation between renal function and the development of bilirubinemia. It is well known that renal function may be disturbed in myocardial failure, and that occasionally the impairment may reach a considerable degree (Resnik and Keefer, 1925). It is conceivable that this damage may play a rôle in favoring the accumulation of bilirubin in the blood because of the inability of the kidney to excrete it properly. But, since patients with severe myocardial insufficiency and jaundice excrete large amounts of bilirubin, it does not seem probable that a single factor such as this should play a very important rôle in determining the amount of bilirubin in the blood.

6. Mechanical obstruction of the bile passages. Eppinger (23) has described the occurrence of so-called bile thrombi in the liver of chronic passive congestion, and has suggested that these cause a certain degree of obstructive jaundice. Eppinger admitted, however, (1923) that obstructive jaundice caused by bile thrombi could not be the sole, 
nor even an important factor in bringing about jaundice in myocardial failure, since bile thrombi are found usually only with difficulty or are entirely absent, even though jaundice is present.

7. Hematinemia. Schottmüller (1914), Thörmahlen (1918) and others have described cases, of extravasation of blood into the tissues, including cases of pulmonary infarction, in which jaundice was due apparently to the presence of hematin in the blood serum. In the cases of jaundice following pulmonary infarction that we have observed, there has been practically always associated bilirubinuria; in two cases, it was shown that the bilirubin content of the blood increased markedly at the time jaundice appeared. In our cases, then, one can account for the development of jaundice purely by the increased bilirubin content of the blood. There may be other cases, however, in which jaundice is due to hematinemia; the differentiation of these cases from those in which bilirubin is the jaundice-producing pigment must be made by the van den Bergh test and spectroscopic examination of the blood.

We have discussed in considerable detail the various factors that may be at work in the production of jaundice in myocardial insufficiency, and in some measure their probable importance. We wish particularly to stress the conception that anoxemia may be of great significance in these, and undoubtedly in other cases of jaundice. We do not propose to discuss in detail, at this time, the relation of anoxemia to these other instances of jaundice; it will suffice to mention one, namely, that occurring in lobar pneumonia. This disease is occasionally associated with conspicuous jaundice, and more frequently with latent jaundice (Lepehne, 1921) (Eppinger, 1923). Histological examination of the liver in fatal cases usually shows the changes that are commonly found in other infectious diseases, namely, cloudy swelling of the parenchymal cells. While it is true that there is increased blood destruction in this disease, particularly in the lungs, it is highly probable that anoxemia, which is usually present and which often may be extreme, plays an important rôle in reducing the function of the liver.

\section{SUMMARY}

In a group of animal experiments, it has been demonstrated that anoxemia may depress the function of damaged livers to such an extent 
that bilirubinemia appears. Reasons were given for assuming that pulmonary infarction in patients with myocardial insufficiency produces anoxemia, probably severe in some cases; and it was chiefly to increased anoxemia that we ascribed the sudden appearance of jaundice in these patients. It was also shown that anoxemia failed to produce bilirubinemia when the liver was normal and when anoxemia, even though severe, was present for several hours only. When uninjured livers were, however, subjected to anoxemia, histological examination showed beginning central necrosis of the lobules. The suggestion was made, therefore, that not only does anoxemia depress the function of the liver, when already damaged, but that anoxemia, if it is of sufficient severity and long standing, may actually cause, in part at least, the anatomical changes which one sees in chronic passive congestion. The various factors, and their probable importance were discussed, that may play a rôle in "cardiac" jaundice, particularly with reference to that which appears after pulmonary infarction. Finally, it was pointed out that anoxemia may be of importance in causing jaundice that is associated with other diseases, such as lobar pneumonia.

\section{BIBLIOGRAPHY}

Binger, C. A. L., Brow, G. R., and Branch, A.: Jour. Clin. Invest., 1924, i, 155. Experimental Studies on Rapid Breathing. II. Tachypnoea, Dependent upon Anoxemia, Resulting from Multiple Emboli in the Larger Branches of the Pulmonary Artery.

Eppinger, H.: Ergebn. d. inn. Med. u. Kinderh., 1908, i, 107. Ikterus.

Eppinger, H.: In Kraus u. Brugsch, Handb. d. spec. Path. u. Therap., Berlin, 1923, vi, 293. Allgemeine únd specielle Pathologie des Ikterus.

Fishberg, A. M.: Jour. Amer. Med. Assoc., 1923, lxxx, 1516. Jaundice in Myocardial Insufficiency.

Gardner, G. H., Grove, R. C., Gustafson, R. K., Maire, E. D., Thompson, M. J., Wells, H. S., and Lamson, P. D.: Bull. Johns Hopkins Hosp., 1925, xxxvi, 107. Studies on the Pathological Histology of Experimental Carbon Tetrachloride Poisoning.

Keefer, C. S., and Resnik, W. H.: Jaundice following Pulmonary Infarction in Patients with Myocardial Insufficiency. I. A Clinical Study. Jour. Clin. Invest., 1926, ii, 375.

Lepehne, G.: Ergebn. d. inn. Med. u. Kinderh., 1921, xx, 221. Pathogenese des Ikterus. 
Lamson, P. D., Gardner, G. H., Gustafson, R. K., Mair, E. D., McLean, A. J., and Wells, H. S.: Jour. Pharmacol. and Exper. Therap., 1923, zxii, 216. The Pharmacology and Toxicology of Carbon Tetrachloride.

MacCallum, W. G.: Textbook of Pathology, Ed. 3, Philadelphia, p. 485.

McMaster, P. D., Broun, G. O., and Rous, P.: Jour. Exper. Med., 1923, xxxvii, 395. Studies on the Total Bile. I. The Effects of Operation, Exercise, Hot Weather, Relief of Obstruction Intercurrent Disease, and other Normal and Pathological Influences.

McNee, J. W.: Quart. Jour. Med., 1922-23, xvi, 390. Critical Review. Jaundice: A Review of Recent Work.

McNee, J. W., and Keefer, C. S.: Brit. Med. Jour., 1925, ii, 52. The Clinical Value of the Van Den Bergh Reaction for Bilirubin in Blood, with Notes on Improvements in its Technique.

Resnik, W. H., and Rich, A. R.: (In press).

Resnik, W. H.: Jour. Clin. Invest., 1925, ii, 93, 117, 125. The Effect of Anoxemia on the Heart. I, II, III.

Resnik, W. H., and Keefer, C. S.: Jour. Amer. Med. Assoc., 1925, 1xxxv, 1553. The Significance of Edema of the Face in Myocardial Insufficiency.

Rich, A. R.: Physiol. Rev., 1925, v, 182. The Formation of Bile Pigment.

Rous, P., Broun, G. O., and McMaster, P. D.: Jour. Exper. Med., 1923, xxxvii, 421. Studies on the Total Bile. II. The Relation of Carbohydrates to the Output of Bile Pigment.

Schottmüller, H.: Münch. med. Wchnschr., 1914, lxi, 230. Ueber Ikterus im allgemeinen und bei Extrauteringravidität im besonderen.

Thormählen, P.: Mitt. a. d. Grenz. d. Med. u. Chir., 1918, xxx, 697. Hämatinämie und Hämatinikterus bei unterbrochener Tubenschwangerschaft. 